\author{
Contato \\ Rua Dois, n 590 - apto. 1302 \\ Edificio Porto Mayor - setor Oeste \\ $74110-130$ - Goiânia - Goiás \\ albertobaena859@gmail.com
}

\section{AS VICE-RAINHAS E O EXERCÍCIO DO PODER NA NOVA ESPANHA (SÉCULOS XVI E XVII)}

\section{Alberto Baena Zapatero*}

Universidade Federal de Goiás

Goiânia - Goiás - Brasil

\title{
Resumo
}

Este artigo trata da corte vice-reinal mexicana ao longo dos séculos XVI e XVII, refletindo sobre um dos aspectos menos trabalhados pela historiografia especializada: o papel das vice-rainhas e seus cortejos. A investigação aprofunda o estudo do significado de suas relações com a sociedade local e sua participação no exercício quotidiano da autoridade. O trabalho não se centrará exclusivamente na figura das vice-rainhas, ocupando-se também de todas as mulheres que formaram seu cortejo e participaram das dinâmicas sociais e políticas da corte mexicana. Essas damas, que poderiam ser de origem peninsular ou criollas (mulheres de origem espanhola nascidas na América), permaneceram anônimas para os historiadores, e seu papel é fundamental para entendermos as estratégias políticas e sociais desenvolvidas na corte.

\section{Palavras-chave}

vice-rainhas - gênero - México.

* Doutor em História pela Universidad Autónoma de Madrid. Professor da Universidad de Salamanca. Professor na Faculdade de História da Universidade Federal de Goiás e membro do programa de pós-graduação da mesma universidade. 


\author{
Contact \\ Rua Dois, n 590 - apto. 1302 \\ Edificio Porto Mayor - setor Oeste \\ $74110-130$ - Goiânia - Goiás \\ albertobaena859@gmail.com
}

\section{THE VICEREINES}

AND THE EXERCISE

OF POWER IN NEW

SPAIN $\left(16^{\text {TH }}\right.$ AND $17^{\text {TH }}$

CENTURIES)

\author{
Alberto Baena Zapatero
}

Universidade Federal de Goiás

Goiânia - Goiás - Brazil

\begin{abstract}
This article examines the Mexican viceroyalty court throughout the sixteenth and seventeenth centuries, reflecting on one of the less analyzed aspects by specialized historiography: the role of the vicereine and their entourage. Our research studies the significance of their relations with local society and their participation in the everyday exercise of authority. We will not only focus exclusively on the figure of the vicereines, but also examine the role of all those women who belonged to their entourages and participated in the social and political dynamics in the Mexican Court. These ladies, who could be European or creole (Spanish women born in America), remained anonymous to historians, and their role is key to understand the political and social strategies around the Court.
\end{abstract}

\title{
Keywords
}

New Spain - vicereines - gender - Mexico. 
Não há corte, por maior e maravilhosa que seja, que atinja valor, nem brilho ou alegria sem damas. ${ }^{1}$

\section{Introdução}

Esta citação forma parte da obra Il cortegiano, de Baldassare Castiglione, publicada pela primeira vez na Itália, em 1528, a partir de onde se difundiu por toda a Europa. Na Espanha, o livro foi traduzido por Juan Boscán em 1534, sob o patrocínio de Gerónima Palova de Almogavar, alcançando um enorme sucesso como guia de bom comportamento. $\mathrm{O}$ autor dedicava uma das quatro partes da obra a descrever as qualidades que deveria possuir a "perfeita dama", concedendo-lhe uma importância capital como reflexo da grandeza de qualquer corte. Apesar das suas palavras, na atualidade, a historiografia sobre a América Espanhola parece ter esquecido as cortesãs, relegando-as a um papel secundário que não foi percebido dessa maneira pelos seus contemporâneos. ${ }^{2}$

Desde que Norbert Elias em 1969 destacou a relevância da corte na Europa e defendeu a necessidade de entendê-la a partir de uma metodologia que aproximasse a história e a sociologia, realizaram-se novos trabalhos que redefiniram a imagem dessa instituição central. No que concerne especificamente à monarquia espanhola, o tema tem sido estudado por investigadores como José Martínez Millán, Pilar Latasa, Christian Büschges, Alejandro Cañeque, Antonio Álvarez-Ossorio Alvariño, Horst Pietschmann ou Manuel Rivero Rodríguez, que ao longo das últimas décadas têm denunciado a necessidade de aprofundar o conhecimento acerca de cada uma das cortes que compuseram o império e de dar um enfoque global aos resultados. ${ }^{3}$ Para o

\footnotetext{
1 Tradução do autor. CASTIGLIONE, Baldassare. El cortesano. Madrid: Espasa-Calpe, 1984, p. 231.

2 Com a palavra "cortesã" se referem às damas que faziam vida na corte. Resultaria interessante pesquisar as causas que levaram a associar este termo no uso do espanhol a "mujer de costumbres libres" ou "ramera de calidad". Diccionario de la Real Academia Española de la lengua.

3 Sobre o debate metodológico e as novas abordagens na investigação das cortes na monarquia hispânica ver: LATASA, Pilar. La corte virreinal novohispana: el virrey y su casa, imágenes distantes del rey y su corte (s. XVII). In: CONGRESSO INTERNACIONAL DE AHILA: AMÉRICA LATINA: OUTRO OCCIDENTE? DEBATES DO FINAL DO MILENIO, 12. Atas... Porto: Centro Leonardo Coimbra, Faculdade de Letras da Universidade do Porto, 2001, p. 114-130. BÜSCHGES, Christian. Del criado al valido: el padronazgo de los virreyes de Nápoles y Nueva España (primera mitad del siglo XVII). In: CANTÙ, Francesca (ed.). Las cortes virreinales de la Monarquía española: América e Italia. Roma: Viella Libreria Editrice, 2008, p. 157-181. ALVARIÑO, Antonio
} 
efeito, estes historiadores assinalaram novos caminhos pelos quais se deveria dirigir a investigação: o entorage do vice-rei, a prática quotidiana do poder e seu patronato, a instituição como centro difusor de cultura, a etiqueta e os cerimoniais, os processos de socialização que tinham lugar durante a festa cortesã, ou as relações entre arte e poder, entre muitos outros.

Infelizmente, apesar dos desejos de renovação e das advertências de Castiglione, as mulheres não são ainda consideradas dentro dos novos caminhos propostos, continuando ausentes nas temáticas abordadas pela maioria dos autores. Entre as mais recentes obras coletivas dedicadas a descrever e comparar as cortes vice-reinais na monarquia espanhola, não se encontra nenhum trabalho dedicado à significação política, simbólica ou social das vice-rainhas e dos seus cortejos. Os últimos projetos publicados reproduzem o esquema político-jurídico tradicional e não concedem um capítulo às mulheres e à sua atividade cortesã. ${ }^{4}$ Nesse sentido, os trabalhos dirigidos por Martínez Millán sobre as casas das rainhas de Espanha e Portugal supõem um excepcional esforço, mas está ainda por demonstrar se ele marcou verdadeiramente um câmbio de rumo nessa tendência e se no futuro se estenderá ao resto de cortes vice-reinais. ${ }^{5}$

\footnotetext{
Álvarez-Ossorio. La Corte: un espacio abierto para la historia social. In: CASTILLO, Santiago (ed.). La historia social en España: actualidad y perspectivas. Zaragoza: Siglo XXI, 1991, p. 247-260.

MILLÁN, José Martínez. La corte de la Monarquía Hispánica. Studia historica: historia moderna, Madrid, vol. 28, 2006, p. 17-61. CAÑEQUE, Alejandro. Cultura vicerregia y Estado colonial: una aproximación crítica al estudio de la historia política de la Nueva España. Historia Mexicana, Fuentes del Pedregal, vol. LI, n. 1, 2001, p. 5-57. PIETSCHMANN, Horst. La corte virreinal de México en el siglo XVII en sus dimensiones jurídico-institucionales, sociales y culturales: aproximación al estado de la investigación. In: BOSSE, Monika \& STOLL, André. La creatividad femenina en el mundo barroco hispánico: María de Zayas, Isabel Rebeca Correa, Sor Juana Inés de la Cruz. Erfurt: Reichenberger, 1999, p. 481-497. RODRÍGUEZ, Manuel Rivero. Court studies in the Spanish world. In: FANTONI, Marcello (dir.). The court in Europe. Roma: Bulzoni, 2012, p. 135-147.

${ }^{4}$ CANTÙ, Francesca (ed.). Las cortes virreinales de la Monarquía española: América e Italia. Roma: Viella Libreria Editrice, 2008; CARDIM, Pedro E PALOS, Joan-Lluís (ed.). El mundo de los virreyes en las monarquías de España y Portugal. Madrid: Iberoamericana, 2012.

No último livro de Manuel Rivero Rodríguez, também não se concede um espaço às mulheres, apesar de que num artigo anterior este mesmo autor assinalara a relevância do estudo das vice-rainhas. RODRÍGUEZ, Manuel Rivero. La edad de oro de los virreyes: el virreinato en la Monarquía Hispánica durante los siglos XVI y XVII. Madrid: Akal, 2011. RODRÍGUEZ, Manuel Rivero. Como reinas: el virreinato en femenino (apuntes sobre la Casa y Corte de las virreinas). In: MILLÁN, José María Martínez \& LOURENÇO, Paula Marçal (ed.). Las relaciones discretas entre las Monarquías Hispana y Portuguesa: las Casas de las Reinas (siglos XV-XIX), vol. 2. Madrid: Polifemo, 2009, p. 789-818.

${ }_{5}$ MILLÁN, José Martínez (ed.). Las relaciones discretas entre la Monarquía Hispana y Portuguesa: las casas de las reinas (s. XV-XIX), vol. 3. Madrid: Polifemo, 2008.; MILLÁN, José Martínez \& VISCEGLIA, María Antonietta (ed.). La monarquía de Felipe III, vol. 4. Madrid: Mapfre, 2008.
} 
No caso da América Espanhola, até o momento existem poucas investigações consagradas a suas cortes. Tanto no México como no Peru se começa timidamente a caminhar nessa direção, mas muitas são descritivas e não indagam sobre o significado dessa instituição como espaço político, social e cultural próprio. ${ }^{6}$ Se existem ainda grandes lacunas relativas ao exercício do poder na Nova Espanha (atualmente México e parte dos Estados Unidos), os vazios do papel público desempenhado pelas vice-rainhas são muito maiores. $^{7}$ Excluídas tradicionalmente desses estudos pelo fato de a vida social e política serem consideradas espaço exclusivo dos varões, o papel das mulheres era reduzido à condição de meras companheiras passivas de seus

${ }_{6}$ Os estudos sobre a corte mexicana começam com os trabalhos publicados por Artemio de Valle-Arizpe, Ernesto de la Torre Villar e Antonio Rubial. ARIZPE, Artemio de Valle. Virreyes y virreinas de la Nueva España. Ciudad de México: Porrúa, 2000; RUBIAL, Antonio. Monjas, cortesanos y plebeyos: la vida cotidiana en la época de Sor Juana. Ciudad de México: Taurus, 2005, p. 118-135. VILLAR, Ernesto de la Torre. Advertencias acerca del sistema virreinal novohispano. Anuario Mexicano de Historia del Derecho, Ciudad de México, vol. 3, 1991, p. 261-290. Num segundo momento aparecem o capítulo escrito por Francisco Iván Escamilla na obra coletiva sobre a historia de la vida cotidiana en México, a análise geral dos vice-reinos feita por Manuel Rivero Rodríguez, as numerosas publicações de Alejandro Cañeque sobre o exercício do poder vice-reinal e a sua linguagem simbólica, e os resumos de Marcello Carmagnani, Christian Büschges e Christoph Rosenmüller. ESCAMILLA, Iván. La corte de los virreyes. In: RUBIAL, Antonio (ed.). Historia de la vida cotidiana en México, vol. 2. Ciudad de México: Fondo de Cultura Económica, 2005, p. 371-406; CAÑEQUE, Alejandro. The king's living image: the culture and politics of viceregal power in Colonial Mexico. New York: Routledge, 2004; CAÑEQUE, Alejandro. El poder transfigurado: el virrey como "la viva imagen del rey" en la Nueva España de los siglos XVI y XVII. In: MAZÍN, Oscar (ed.). Las representaciones del poder en las sociedades hispánicas. Ciudad de México: El Colegio de México e Centro de Estudios Históricos, 2012, p. 301-335; CAÑEQUE, Alejandro. De sillas y almohadones o de la naturaleza ritual del poder en la Nueva España de los siglos XVI y XVII. Revista de Indias, Madrid, vol. LXIV, n. 232, 2004, p. 609-634; CAÑEQUE, Alejandro. Imaging the Spanish Empire: the visual construction of imperial authority in Habsburg New Spain. Colonial Latin American Review, London, vol. 19, n. 1, 2010, p. 29-68. CAÑEQUE, Alejandro. De parientes, criados y gracias: cultura del don y poder en el México colonial, siglos XVI-XVII. Histórica, Lima, vol. 29, n. 1, 2005, p. 3-42. RODRÍGUEZ, Manuel Rivero. La edad de oro de los virreyes: el virreinato en la Monarquía Hispánica durante los siglos XVI y XVII. Madrid: Akal, 2011. CARMAGNANI, Marcello. El virrey y la corte virreinal en Nueva España. In: CANTÙ, Francesca (ed.). Las cortes virreinales de la Monarquía española: América e Italia. Roma: Viella Libreria Editrice, 2008, p. 65-77; BÜSCHGES, Christian. La corte virreinal como espacio político: el gobierno de los virreyes de la América hispánica entre monarquía, élites locales y casa mobiliaria. In: CARDIM, Pedro \& PALOS Joan-Lluís (ed.). El mundo de los virreyes en las monarquías de España y Portugal. Madrid: Iberoamericana Vervuert, 2012, p. 319-344.

7 Sobre as vice-rainhas novo-hispanas, existem os seguintes trabalhos: ZAPATERO, Alberto Baena. Mujeres novohispanas e identidad criolla (siglos XVI y XVII). Alcalá de Henares: Ayuntamiento de Alcalá de Henares, 2009; ZAPATERO, Alberto Baena. Presencia y representación pública de las virreinas en la Nueva España, siglos XVI y XVII. Colonial Latin American Historical Review, Albuquerque, vol. 2, n. 1, 2014, p. 49-74; FRUTOS, Isabel Arenas. ¿Sólo una virreina consorte de la Nueva España? 1660-1664: la II Marquesa de Leiva y II Condesa de Baños. Anuario de Estudios 
esposos. Isso sucede, em grande parte, ao que Steve Stern descreveu como a atribuição às mulheres de "um papel de símbolos e arquétipos femininos estereotipados que resultam de uma análise marginal, em vez de examiná-las como participantes sociais complexas e importantes, dignas de uma análise centrada em elas". ${ }^{8}$ No entanto, uma nova leitura das tradicionais fontes históricas, e a inclusão de outras, poderá proporcionar um panorama mais completo de sua função e relevância tanto social quanto política.

O seguinte artigo pretende dar resposta, embora de maneira parcial, à pergunta lançada já há mais de uma década por Horst Pietschmann: "Poderia haver corte vice-reinal sem que o vice-rei fosse acompanhado de sua esposa?". Com esse objetivo, refletiremos sobre o papel dessas personagens na reprodução americana do modelo cortesão, sua relevância na representação simbólica da autoridade Real e sua marca no desempenho quotidiano do poder. Por último, é necessário advertir que, por falta de espaço, não se incluirá a análise da contribuição dessas mulheres para a construção de uma representação simbólica do poder político e religioso, um aspecto fundamental e intimamente ligado aos que serão tratados no artigo.

\section{A vice-rainha e os equilíbrios de poder}

Durante o século XVI, a herança organizativa do reino de Aragão e a incapacidade da Coroa espanhola para controlar diretamente um espaço tão grande como o conquistado nas Índias influiu na opção de criar dois novos vice-reinados na América, para representar a autoridade Real. Essas novas cortes e seus vice-reis jogaram, segundo Christian Büschges, "um papel importante para a integração dos territórios e as suas elites políticas

\footnotetext{
Americanos, Sevilla, vol. 67, n. 2, 2010, p. 551-575; RUBIAL, Antonio. Las virreinas novohispanas: presencias y ausencias. Estudios de Historia Novohispana, Ciudad de México, vol. 50, 2014, p. 3-44. Um interessante artigo de Manuel Rivero Rodríguez mostra algumas pistas sobre a importância das vice-rainhas no contexto mais amplo da monarquia hispânica. RODRÍGUEZ, Manuel Rivero. Como reinas: el virreinato en femenino (apuntes sobre la Casa y Corte de las virreinas). In: MILLÁN, José María Martínez \& LOURENÇO, Paula Marçal (ed.). Las relaciones discretas entre las Monarquías Hispana y Portuguesa: las Casas de las Reinas (siglos XV-XIX), vol. 2. Madrid: Polifemo, 2009, p. 789-818.

8 Tradução do autor. STERN, Steve J. La historia secreta del género: mujeres, hombres y poder en México en las postrimerías del periodo colonial. Ciudad de México: Fondo de Cultura Económica, 1999, p. 27-70.

9 Tradução do autor. PIETSCHMANN, Horst. La corte virreinal de México en el siglo XVII en sus dimensiones jurídico-institucionales, sociales y culturales: aproximación al estado de la investigación. In: BOSSE, Monika \& STOLL, André. La creatividad femenina en el mundo barroco hispánico: María de Zayas, Isabel Rebeca Correa, Sor Juana Inés de la Cruz. Erfurt: Reichenberger, 1999, p. 496.
} 
na monarquia"..$^{10}$ Se se pretende analisar o funcionamento cotidiano de tais instituições, deve-se perceber a composição do grupo de cortesãos e sua posição dentro da corte. No que se refere à Nova Espanha, pode-se falar de três grupos fundamentais: o entourage dos vice-reis (familiares e deudos); os ministros e oficiais mais importantes do reino, junto de suas esposas e filhos; e um conjunto heterogêneo de senhores e senhoras locais que acudiam ao palácio na expectativa de alcançar mercês ou vantagens para seus negócios.

Todos os vice-reis, além dos bispos e visitantes deslocados à América (alguns terminariam por ocupar o cargo também), viajavam até seu novo destino acompanhados de um numeroso séquito, formado por parentes, criados ou achegados que esperavam ganhar fortuna graças a seu benfeitor. Durante o século XVII, a Coroa autorizou traslados de 70 a 80 pessoas para o serviço de seu representante e sua família, cifra que nem sempre foi respeitada. Ao conde de Montesclaros, por exemplo, foi permitido levar 70 criados, mas terminou por viajar com 83. ${ }^{11}$ Além disso, houve exceções, como as do conde de Alba de Aliste, o Duque de Alburquerque, ou o conde de Baños, os quais puderam levar até 100 indivíduos. A este número somavam-se as esposas e os filhos dos escolhidos para o serviço. Em alguns casos, o séquito do vice-rei impressionou a tal ponto que estrangeiros como Thomas Gage chegaram a declarar que era "verdadeiramente majestoso, e há quem sustenta que é tão grandioso como os do seu senhor, o rei da Espanha". ${ }^{2}$

O comportamento dos criados influía na imagem de seu senhor e determinava a integração dos recém-chegados a seu novo lar, recomendando-se que fossem moderados e bem educados. Em 1603, Pablo de la Laguna, presidente do Conselho de Índias, forneceu Instrucciones ao futuro vice-rei, Marquês de Montesclaros, para ajudá-lo a governar a Nova Espanha. O oficial Real lembrava a importância de escolher bem os indivíduos que o acompanhariam na viagem, dado que "los buenos criados del virrey es una de las principales causas de que él esté bien visto", e sublinhava sua relevância simbólica para a harmonia do reino:

\footnotetext{
${ }^{10}$ Tradução do autor. BÜSCHGES, Christian. La corte virreinal novohispana: el virrey y su casa, imágenes distantes del rey y su corte (s. XVII). In: CONGRESSO INTERNACIONAL DE AHILA: AMÉRICA LATINA: OUTRO OCCIDENTE? DEBATES DO FINAL DO MILENIO, 12. Atas ... Porto: Centro Leonardo Coimbra, Faculdade de Letras da Universidade do Porto, 2001, p. 114-130.

${ }^{11}$ LATASA, Pilar. Poder y favor en la corte virreinal del Perú: los criados del Marqués de Montesclaros (1607-1615). Histórica, Lima, vol. 36, n. 2, 2012, p. 58-59.

${ }^{12}$ GAGE, Thomas. Viajes por la Nueva España y Guatemala. Madrid: Historia 16, 1987, p. 172-173.
} 
Ante todas cosas, se ha de entender qué cosa es criado del virrey de la Nueva España. Criado del virrey de México es lo propio que su señor en España, porque en aquella tierra no hay más rey que el virrey y los condes y marqueses son sus criados y los oficiales reales, y los grandes son los oidores, alcaldes de Corte, etc. ${ }^{13}$

Os criados trazidos da península formavam, com as famílias criollas que tinham acesso ao palácio vice-reinal, o núcleo forte dos cortesãos, e, como se explicará mais à frente, ambos os grupos se alternavam entre disputas e alianças para concorrer às mercês reais. ${ }^{14}$ Portanto, os governantes teciam redes de patronato que lhes proporcionavam deudos nascidos em ambos os lados do Atlântico.

Nem sempre os vice-reis eram casados, principalmente os religiosos. Quando eles já haviam constituído família, as Leis de Índias obrigavam que as mulheres viajassem com eles, sobretudo porque a Coroa espanhola pretendia preservar na América o papel da família como instituição de organização social básica. Nesse sentido, os governantes deveriam apresentar comportamento exemplar e dissuadir a proliferação de pessoas solteiras ou o "pecado" da bigamia. No entanto, houve casos de vice-reis se trasladarem à América sem suas esposas e filhos, ou com famílias que chegavam muito tempo depois.

As futuras vice-rainhas também viajavam com um pequeno grupo de dueñas e damas, a maioria solteiras e vigiladas pelas primeiras. ${ }^{15}$ À semelhança do que acontecia com o esposo e os homens que o seguiam, essas mulheres acompanhavam sua senhora para servi-la, acalentando o desejo de aproveitar a posição privilegiada de sua patrona na corte americana para obter uma boa "colocação".

Como é possível observar na tabela a seguir, o número de mulheres solteiras selecionadas pelas vice-rainhas durante os séculos XVI e XVII variou entre 8 a 29. Em 1660, o rei autorizou o Conde de Baños a viajar com sua

\footnotetext{
${ }^{13}$ VILLAR, Ernesto de la Torre. Advertencias acerca del sistema virreinal novohispano. Anuario Mexicano de Historia del Derecho, Ciudad de México, vol. 3, 1991, p. 299-300.

${ }^{14}$ Com a palavra criollo se referem todos os filhos de espanhóis nascidos na América, embora nos últimos anos o termo se tenha utilizado de maneira mais ampla, incluindo os espanhóis peninsulares ou americanos com interesses locais opostos aos da Coroa.

${ }^{15}$ Segundo o Dicionário de autoridades, de 1732, dueñas seriam "aquellas mugeres viudas y de respeto, que se tienen en palacio y en las casas de los señores para autoridad de las antesalas, y guarda de las demas criadas. Estas andaban vestidas de negro y con unas tocas blancas de lienzo, ó beatilla, que pendiendo de la cabeza, baxaban por la circunferencia del rostro, $y$ uniéndose debaxo de la barba, se prendian en los hombros, $y$ descendian por el pecho hasta la mitad de la falda; $y$ asimismo llevaban siempre un manto negro prendido por los hombros, desde donde remataban las tocas de la cabeza" Diccionario de la Real Academia Española de la Lengua, 1732. Disponível em: http://bit.ly/2rSI4OK. Acesso em: 21 jun. 2016.
} 
esposa, Mariana Isabel de Leiva y Mendoza, Marquesa de Leiva, com filho e netos. Entre os acompanhantes dos futuros vice-reis, foram autorizadas 9 criadas casadas, que viajaram com seus maridos, 20 solteiras e 2 capelães - a maior proporção de mulheres em relação ao total de criados peninsulares durante o período estudado. ${ }^{16}$ Depois viria María Andrea de Guzmán, Condessa de Moctezuma, que levou 24 damas e 6 escravas. ${ }^{17}$ Todas as damas casadas viajavam com seus maridos, como as cinco damas que seguiram Leonora María del Carretto e Marquesa de Mancera até a Nova Espanha. ${ }^{18}$

${ }^{16}$ AGI, Contratación, 5432, N.2, R.16. Relación de personas que acompañan a Juan de Leyva y de la Cerda, Marqués de Leiva y Ladrada, Conde de Baños, virrey de México, Sevilla, 29 abr. 1660.

${ }^{17}$ AGI, Contratación, 5458, N.1, R.27. Expediente de información y licencia de pasajero a Indias de José Sarmiento de Valladares, virrey de Nueva España, a Nueva España. Sevilla, 20 jul. 1696.

${ }^{18}$ AGI, Contratación, 5434, N.1, R.46. Expediente de información y licencia de pasajero a indias de Antonio Sebastián de Toledo Molina y Salazar, Marqués de Mancer. Sevilla, 8 de abril de 1664. AGI, Contratación, 5540A, L.1, F.16v-17r. Pasajeros a Indias. Sevilla, 20 abr. 1664. 


\section{Tabela 1}

Vice-rainhas novo-hispanas e criadas do século XVII'

\begin{tabular}{|c|c|c|c|}
\hline $\begin{array}{l}\text { Ano da } \\
\text { viagem }\end{array}$ & Vice-rainha & $\begin{array}{c}\text { Número de } \\
\text { criadas em } \\
\text { relação ao total }\end{array}$ & Nomes das criadas \\
\hline 1603 & $\begin{array}{c}\text { Ana de Medoza, } \\
\text { Marquesa de } \\
\text { Montesclaros }\end{array}$ & $22 / 84$ & $\begin{array}{l}\text { - Doña Catalina de Arce } \\
\text { - Doña Juana de Mendoza } \\
\text { - Doña Mencía Merino } \\
\text { - Doña Francisca Merino } \\
\text { - Doña Beatriz del Castillo } \\
\text { - Doña Josefa de Torres } \\
\text { - Luisa del Castillo } \\
\text { - Doña Isabel de Ayala } \\
\text { - Inés Alonso } \\
\text { - María Muñoz } \\
\text { - Magdalena de cortes } \\
\text { - Ana Ortiz } \\
\text { - Doña Feliciana de Rivera } \\
\text { - Doña Catalina de Rojas } \\
\text { - Doña Ana de la Mota } \\
\text { - Isabel Manrique } \\
\text { - Doña Isabel de Medina } \\
\text { - Doña Mencia de la Vega } \\
\text { - Maria Luengo } \\
\text { - Doña Inés de Mendoza } \\
\text { - Catalina Sánchez } \\
\text { - Joana Ramirez }\end{array}$ \\
\hline
\end{tabular}

19 Documentos do AGI consultados para elaborar a tabela: Contratación, 5273, N.3; Pasajeros, L.9, E.2681; Pasajeros, L.9, E.2682; Contratación, 5324, N.1; Contratación, 5389, N.1; Indiferente, 453, L.A18, F.49; Contratación, 5422, N.34; Contratación, 5424, N.2, R.11; Contratación, 5429, N.75; Contratación, 5539, L.5, f.371-372v; Contratación, 5432, N.2, R.16; Contratación, 5540A, L.1, f.16v-17; Contratación, 5434, N.1, R.46; Contratación, 5540A, L.1, f.126v-127v; Contratación, 5443, N.2, R.127; Contratación, 5447, N.2, R.23; Contratación, 5450, N.47; Contratación, 5458, N.1, R.27; Contratación, 5421, N.48. (Não se trata de uma lista completa de vice-rainhas, pois não foi possível localizar a documentação da viagem de todas.) 


\begin{tabular}{|c|c|c|c|}
\hline 1612 & $\begin{array}{l}\text { María Ana Riederer } \\
\text { de Para, Marquesa de } \\
\text { Guadalcazar }\end{array}$ & $14 / 70$ & $\begin{array}{c}\text { - Inés de Soto, natural de Madrid } \\
\text { - Beatriz Meléndez, } \\
\text { natural de Sevilla } \\
\text { - Leonor Díaz del Peso, } \\
\text { natural de Salamanca } \\
\text { - Gracia Yáñez, natural de Madrid } \\
\text { - Luisa de Mario, natural de Madrid } \\
\text { - Isabel de Monreal, } \\
\text { natural de Belmonte } \\
\text { - Jerónima Cortés, } \\
\text { natural de Madrid } \\
\text { - María de Orbaneja, } \\
\text { natural de Córdoba } \\
\text { - Inés de Valverde, } \\
\text { natural de Córdoba } \\
\text { - Catalina de León, natural de Rute } \\
\text { - María López, natural de Brunete } \\
\text { - Catalina Fernández de Toro, } \\
\text { natural de Córdoba } \\
\text { - Cristina de Parraga, } \\
\text { natural de Alcobendas } \\
\text { - Sebastiana de la Cruz, } \\
\text { natural de Baena }\end{array}$ \\
\hline 1635 & $\begin{array}{l}\text { Antonia de Sandoval y } \\
\text { Afán de Rivera, } \\
\text { Marquesa de Cadereyta }\end{array}$ & $\begin{array}{l}24 \text { mulheres a seu } \\
\text { serviço por Real } \\
\text { Cédula }\end{array}$ & \\
\hline 1640 & $\begin{array}{l}\text { Juana de Zuñiga y } \\
\text { Mendoza (Marqués } \\
\text { de Villena y Duque de } \\
\text { Escalona) }\end{array}$ & $2 / 78$ & $\begin{array}{c}\text { - Micaela Manso, dueña, } \\
\text { natural de Arenas } \\
\text { - Catalina de Hervias, "medias tocas", } \\
\text { vizinha de Alarcón }\end{array}$ \\
\hline 1642 & $\begin{array}{l}\text { Antonia de Acuña y de } \\
\text { Guzmán, Condesa de } \\
\text { Salvatierra }\end{array}$ & $8 / 63$ & $\begin{array}{c}\text { - María Suárez } \\
\text { - Francisca de León, dueña } \\
\text { - Mencía Niño de Colmenares } \\
\text { - Juana de Miranda } \\
\text { - María de Pereira } \\
\text { - Ana de la Puente, dueña } \\
\text { - Beatriz de Castro } \\
\text { - Francisca de Castro, } \\
\text { "mozas de cámara" }\end{array}$ \\
\hline 1650 & $\begin{array}{c}\text { Condesa de Alba de } \\
\text { Aliste }\end{array}$ & $\begin{array}{l}\text { 3, embora se } \\
\text { assinalem } 16\end{array}$ & $\begin{array}{l}\text { - Ana María Ruiz } \\
\text { - Juana Sánchez } \\
\text { - María Hidalgo }\end{array}$ \\
\hline
\end{tabular}




\begin{tabular}{|c|c|c|c|}
\hline 1653 & $\begin{array}{c}\text { Juana Francisca Díez } \\
\text { de Aux II Marquesa de } \\
\text { Cadreita (esposa do VIII } \\
\text { Duque de } \\
\text { Alburquerque) }\end{array}$ & $18 / 100$ & $\begin{array}{c}\text { Damas da Duquesa: } \\
\text { - Doña Francisca Ruiz } \\
\text { - Doña Francisca Arroyo } \\
\text { - Doña Ana Arroyo } \\
\text { - Doña Inés Maldonado } \\
\text { - Doña María Maldonado } \\
\text { - Doña Antonia de Murcia } \\
\text { - Doña Mariana de los Cobos } \\
\text { - Doña Antonia Escudero } \\
\text { - Doña Isabel Vazquez } \\
\text { - Doña Maria Manuelas } \\
\text { - Doña Gerónima de Arroyo, dueña } \\
\text { - Doña María de Guevara, idem } \\
\text { - Doña Victoria de Avila, idem } \\
\text { Da Câmara: } \\
\text { - Josefa Galindo } \\
\text { - Melchora Hernández } \\
\text { - Feliciana Sanchez, negra } \\
\text { - María de San Nicolas, negra } \\
\text { - Esperanza, negra }\end{array}$ \\
\hline 1660 & $\begin{array}{c}\text { Mariana Isabel de Leiva } \\
\text { y Mendoza, Marquesa } \\
\text { de Leiva y Condesa de } \\
\text { Baños. Viajam também } \\
\text { o filho, Pedro de Leyva, } \\
\text { e sua mulher, María de } \\
\text { Alencastre, com seus } \\
\text { filhos. }\end{array}$ & $\begin{array}{c}\text { 29/100 - Na docu- } \\
\text { mentação refere-se } \\
\text { a autorização para } \\
\text { levar } 9 \text { criadas } \\
\text { casadas que via- } \\
\text { jariam com seus } \\
\text { maridos, } \\
20 \text { criadas solteiras e }^{2} \text { capelães }^{*}\end{array}$ & $\begin{array}{c}\text { - Doña Isabel de Bustamante } \\
\text { - Doña Ana Gil de Rozas } \\
\text { - Doña Ángela Gomez } \\
\text { - Doña Gabriela de Baños } \\
\text { - Doña Bernarda Bernal } \\
\text { - Doña Catalina de Salazar } \\
\text { - Doña Isabel de Baraona } \\
\text { - Doña María Calderón } \\
\text { - Doña Francisca Tordesillas } \\
\text { - Doña María Aguado } \\
\text { - Doña Francisca de Torres y Bargas } \\
\text { - Doña Phelipa de Balderrama } \\
\text { - Thomasa Fernández } \\
\text { - Doña Violante de Baños } \\
\text { - Doña Elena de Baños } \\
\text { - María de Benabente } \\
\text { - María Antonia }\end{array}$ \\
\hline 1664 & $\begin{array}{c}\text { Leonora María del } \\
\text { Carretto, Marquesa de } \\
\text { Mancera }\end{array}$ & $15 / 50$ & $\begin{array}{l}\text { Licença para levar } 50 \text { criados e } \\
\text { criadas para seu serviço, } 5 \text { casadas } \\
\text { que viajam com seus maridos, } \\
10 \text { criadas solteiras e } 1 \text { capelão. }\end{array}$ \\
\hline
\end{tabular}

* AGI, Contratación, 5432, N.2, R.16. Relación de personas que acompañan a Juan de Leyva y de la Cerda, Marqués de Leiva y Ladrada, Conde de Baños, virrey de México. Sevilla, 29 abr. 1660. 


\begin{tabular}{|c|c|c|c|}
\hline 1680 & $\begin{array}{c}\text { María Luisa Manrique } \\
\text { y Gonzaga, Condesa de } \\
\text { Paredes y Marquesa de } \\
\text { la Laguna }\end{array}$ & $17 / 80$ & $\begin{array}{l}\text { - María de Larrea } \\
\text { - Luisa Solier } \\
\text { - Francisca Riquelme } \\
\text { - Clara Montoza } \\
\text { - Inés de Lezcano } \\
\text { - Catalina Franco } \\
\text { - Antonia Campillos } \\
\text { - Manuela de las Cuevas } \\
\text { - María Ortiz } \\
\text { - María Piñar } \\
\text { - Teresa Ortiz } \\
\text { - Josefa González } \\
\text { - Angela Lozano } \\
\text { - Catalina de Teves } \\
\text { - María Araujo } \\
\text { - María Lucas } \\
\text { - María, "la Negra” }\end{array}$ \\
\hline 1686 & $\begin{array}{c}\text { Antonia Ximénez de } \\
\text { Urrea y Clavero, } \\
\text { Condesa de la Monclova }\end{array}$ & $12 / 78$ & $\begin{array}{c}\text { Mulheres solteiras: } \\
\text { - Mariana Vázquez, } \\
\text { natural de Guetaria } \\
\text { - Francisca Morales, } \\
\text { natural de Torrelaguna } \\
\text { - Teresa de los Ríos, } \\
\text { natural de Tamarit } \\
\text { - Isabel Jiménez, natural de Trujillo } \\
\text { - Ana Rafo de Guarnica, } \\
\text { natural de Madrid } \\
\text { - María Fernández, } \\
\text { natural de Madrid } \\
\text { - María Arizabal de Villarroel, } \\
\text { natural de Madrid } \\
\text { - Ana de Rojas, natural de Cedillo } \\
\text { - Isabel de Gaara, natural de } \\
\text { Santiago de Compostela } \\
\text { - Catalina Fernández, } \\
\text { natural de Lugo } \\
\text { - Teresa Arnalde, natural de Ocaña } \\
\text { - María Gandara, } \\
\text { natural de Santiago de Compostela }\end{array}$ \\
\hline
\end{tabular}




\begin{tabular}{|c|c|c|c|}
\hline 1688 & $\begin{array}{c}\text { María Elvira de Toledo } \\
\text { y Córdoba, Condesa de } \\
\text { Galve }\end{array}$ & $15 / 82$ & $\begin{array}{c}\text { Dueñas e damas: } \\
\text { - Magdalena de Villegas Retes } \\
\text { - Tomasa Ferrando } \\
\text { - Bernarda de Torres } \\
\text { - María Catalina de Torres } \\
\text { - Manuela Rojo } \\
\text { - Teresa de Torres } \\
\text { - Magdalena de las Cuevas } \\
\text { - Antonia de Huya y Toledo } \\
\text { - Alfonsa de Fonseca Piña } \\
\text { - Estefanía de Vozmediano } \\
\text { Criadas da câmara: } \\
\text { - Margarita del Castillo } \\
\text { - Agueda de la Iguera } \\
\text { - Ana Rufel } \\
\text { - Brígida España } \\
\text { - Isabel }\end{array}$ \\
\hline 1696 & $\begin{array}{l}\text { María Andrea de } \\
\text { Guzmán, Condesa de } \\
\text { Moctezuma. } \\
\text { Leva } 4 \text { filhas } \\
\text { (uma própria): } \\
\text { - Teresa de Cárdona, } \\
\text { filha de María Andréa } \\
\text { de Guzmán de idade } \\
\text { de } 7 \text { anos } \\
\text { - Fausta Sarmiento, } \\
\text { filha de } 6 \text { anos } \\
\text { - Melchora Sarmiento, } \\
\text { filha de } 5 \text { anos } \\
\text { - Bernarda Sarmiento, } \\
\text { filha de } 1 \text { ano. }\end{array}$ & $\begin{array}{l}\text { 24/80 (referem-se } \\
\text { seis escravos e seis } \\
\text { escravas) }\end{array}$ & $\begin{array}{l}\text { - Juliana Manjarres } \\
\text { - Beatriz de Morales } \\
\text { - María de Orduña } \\
\text { - Gabriela de Morales } \\
\text { - María de Solís } \\
\text { - Francisca de Vinuesa } \\
\text { - María de Luque } \\
\text { - Beatriz María Dueña } \\
\text { - Antonia Beltrán } \\
\text { - Francisca Serrano } \\
\text { - Antonia Serrano } \\
\text { - Francisca Osorio } \\
\text { - Ana Paula } \\
\text { - María Gregoria } \\
\text { - Francisca Cesarini } \\
\text { - Ignacia Cesarini } \\
\text { - María de Paz } \\
\text { - Josefa Morón } \\
\text { - Rosa Morón } \\
\text { - Mariana Bozomo } \\
\text { - Isabel Gómez con un } \\
\text { niño al pecho } \\
\text { - Jacinta Elguera } \\
\text { - Felipa Díaz } \\
\text { - Antonia Garzón }\end{array}$ \\
\hline
\end{tabular}


Uma vez instalada na Cidade do México, a comitiva da vice-rainha podia se juntar às esposas dos criados de seu marido. Além disso, logo depois de chegar, eram incorporadas a seu cortejo jovens das famílias mais influentes do Reino. Dentro desse grupo de mulheres, encontravam-se as "oidoras" e as "senhoras principais da cidade". ${ }^{20}$ Esse aspecto inclusivo das vice-rainhas foi vital para as elites locais se sentirem integradas à monarquia. Na cultura política da Idade Moderna, o poder se estabelecia com laços de clientelismo e patronato, especialmente na Nova Espanha, onde os representantes do rei estavam longe do centro político. Apesar da presença de instituições de governo e justiça, a Coroa espanhola não tinha um exército na América que a ajudasse a impor sua autoridade. Os representantes reais viam-se constantemente obrigados a negociar com as elites para lograr um consenso que facilitasse a implementação de suas decisões. ${ }^{21}$ Nesse contexto, entende-se o valor de a vice-rainha forjar lealdades entre as damas da elite novo-hispana para conservar a paz do reino. Pablo de la Laguna era consciente dessa função e especificou como a vice-rainha deveria exercer suas funções nas Instrucciones de 1603:

La virreina ha de ser afable con las mujeres principales de la ciudad, hermanándolas y tratándolas con todo el buen término que pudiere, mostrándoles mucha amistad a cada una conforme a su calidad, de tal manera que todas salgan contentas y diciendo bien. ${ }^{22}$

A vice-rainha se ocupava de todos os assuntos que as senhoras do reino demandavam. Essa obrigação ia além da partilha de momentos lúdicos associados à vida cortesã e constituía, acima de tudo, uma tarefa política. Através de suas boas relações com as novo-hispanas, a vice-rainha gerava um clima positivo com a oligarquia local, diluindo as diferenças e ressentimentos entre criollos e peninsulares. Dessa forma, reconhecia-se implicitamente que as damas da corte tinham notável participação nas estratégias informais estabelecidas nas camadas mais altas da sociedade colonial.

A relevância desse cortejo feminino manifestou-se na constante presença da vice-rainha em qualquer evento oficial de carácter político ou religioso, além das frequentes atividades lúdicas que protagonizavam. A religiosa

\footnotetext{
${ }^{20}$ As oidoras eram as mulheres dos oidores, membros da Audiencia.

${ }^{21}$ Sobre a necessidade de aplicar uma política de consenso, ver: LYNCH, John. América latina, entre colonia y nación. Madrid: Crítica, 2001, p. 75-93.

${ }^{22}$ VILLAR, Ernesto de la Torre. Advertencias acerca del sistema virreinal novohispano. Anuario Mexicano de Historia del Derecho, Ciudad de México, vol. 3, 1991, p. 298-299.
} 
e poeta Sor Juana Inés de la Cruz foi dama de companhia da Marquesa de Mancera antes de tomar os votos. Portanto, conhecia bem o funcionamento da corte no México e escreveu bonitos versos sobre a imagem que compunham a vice-rainha e seu cortejo:

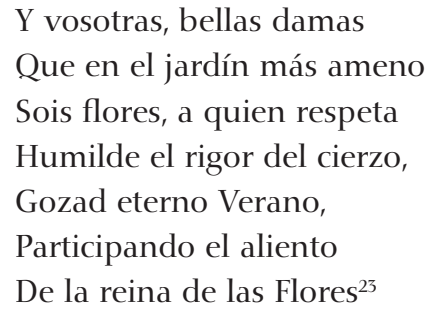

A presença na corte e a proximidade da vice-rainha forneciam a essas criadas o reconhecimento social, mesmo escravas de origem africana. Essa situação resulta surpreendente numa sociedade hierárquica como a novo-hispana e reforça a ideia da relevância concedida ao serviço prestado aos governantes. Assim, em 1656, quando uma escrava negra que era "recamarera" (mulher do serviço) da vice-rainha morreu, seu corpo foi carregado pelos cavalheiros da cidade para ser enterrado na igreja de Santa Teresa, e tanto a nobreza como "todas las religiones y capilla de la catedral" assistiram a seu funeral. ${ }^{24}$ Segundo relatos, essa escrava chegou com o Marquês de Cadereita e se manteve a serviço do palácio até sua morte. Essa anedota demonstra que, da mesma maneira que acontecia com a metáfora solar atribuída aos reis, o contato pessoal e íntimo com vice-reis transmitia parte de seu brilho.

Uma das chaves para compreender o comportamento quotidiano dos cortesãos e cortesãs é considerar as atribuições dos vice-reis. Devido à fraqueza do poder Real na América, a Coroa decidiu outorgar a seus representantes a faculdade de conceder mercês ou ofícios, já que, na opinião de Alejandro Cañeque, isso lhes permitia atingir um duplo objetivo: em primeiro lugar, reforçava sua posição ao fixar uma série de lealdades ligadas diretamente a sua pessoa; em segundo, garantia a fidelidade dos criollos, que se uniam "ao soberano por uma dívida de gratidão, dado que a distribuição

\footnotetext{
${ }^{25}$ CRUZ, Sor Juana Inés de la. Obras completas. Ciudad de México: Fondo de Cultura Económica, 1976, p. 442.

${ }^{24}$ GUIJO, Gregorio María de. Diario, 1648-1664. Ciudad de México: Porrúa, 1953, Tomo II, p. 43.
} 
de mercês realizada pelo vice-rei se fazia em nome do rei". ${ }^{25}$ Ainda assim, Ivan Escamilla lembra que "repartindo favores dessa maneira, os vice-reis terminavam por criar entorno deles uma ampla rede local de clientes, protegidos e cúmplices, a quem utilizavam para encobrir sua participação em lucrativos e ilícitos negócios e empresas". ${ }^{26}$

Os corregimientos e alcaldías mayores eram os prêmios que mais outorgavam os vice-reis, mas também exerciam seu poder de influência quando recomendavam a concessão de petições privadas de mercês ou de cargos de maior categoria, como oidores da Audiencia. Apesar das boas intenções Reais, a valência em outorgar mercês era uma faca de dois gumes, sendo que a obrigação de beneficiar seus criados poderia pôr em perigo o frágil equilíbrio político e social do vice-reino. Como nobre, estava obrigado a atender às expectativas de seus achegados, fornecendo-lhes recompensas, cargos ou, em numerosas ocasiões, promovendo um casamento vantajoso com alguma rica herdeira novo-hispana. No entanto, se se excedia seu desejo de agradar seus criados, poderia gerar um grande mal-estar entre os criollos excluídos.

As pesquisas desenvolvidas por Nelly Porro Girard, Alejandro Cañeque, Christian Büschges, Eduardo Torres Arancivia, José de la Puente ou Pilar Latasa demonstram a falta de zelo por parte dos vice-reis da Nova Espanha e do Peru, que favoreceriam seus deudos com as melhores recompensas, embora não só a eles. ${ }^{27}$ Algumas famílias criollas puderam também beneficiarse desse sistema que concedia algumas liberdades ao governador, fosse de

\footnotetext{
${ }^{25}$ Tradução do autor. CAÑEQUE, Alejandro. De parientes, criados y gracias. Cultura del don y poder en el México colonial, siglos XVI-XVII. Histórica, Lima, vol. 29, n. 1, 2005, p. 11.

${ }^{26}$ Tradução do autor. ESCAMILLA, Iván. La corte de los virreyes. In: RUBIAL, Antonio (ed.). Historia de la vida cotidiana en México, vol. 2. Ciudad de México: Fondo de Cultura Económica, 2005, p. 379.

${ }^{27}$ PORRO GIRARDI, Nelly R. Los criados de los virreyes, un ingrediente de la corrupción en Indias. In: PINARD, Gustavo E MERCHÁN, Antonio (ed.). Libro homenaje in memoriam Carlos Díaz Rementería. Huelva: Universidad de Huelva, 1998, p. 591-606; BÜSCHGES, Christian. Del criado al valido: el padronazgo de los virreyes de Nápoles y Nueva España (primera mitad del siglo XVII). In: CANTÙ, Francesca (ed.). Las cortes virreinales de la Monarquía española: América e Italia. Roma: Viella Libreria Editrice, 2008, p. 157-181; ARANCIVIA, Eduardo Torres. Corte de virreyes: el entorno del poder en el Perú del siglo XVII. Lima: Pontificia Universidad Católica del Perú, 2006, p. 165-172; CAÑEQUE, Alejandro. De parientes, criados y gracias. Cultura del don y poder en el México colonial, siglos XVI-XVII. Histórica, Lima, vol. 29, n. 1, 2005, p. 3-42; BRUNKE, José de la Puente. Monarquía, gobierno virreinal y élites: el Perú en el siglo XVII. In: CANTÚ, Francesca (ed.). Las cortes virreinales de la Monarquía española: América e Italia. Roma: Viella Librería, 2008, p. 103-118; LATASA, Pilar. ¿Criollismo peruano versus administración española? In: MAZZOTTI, José Antonio (ed.). Perú Hoy. Cambridge: David Rockefeller Center for Latin American Studies, 1999; LATASA, Pilar. Poder y favor en la corte virreinal del Perú: los criados del Marqués de Montesclaros (1607-1615). Histórica, Lima, vol. 36, n. 2, 2012, p. 49-84.
} 
maneira direta ou através do matrimônio das filhas com algum dos oficiais Reais. O primeiro dos vice-reis da Nova Espanha, Antonio de Mendoza, considerava uma obrigação inerente a seu cargo a procura de casamentos convenientes às criollas das principais famílias, e assim o recomendava ao seu sucessor, Luis de Velasco:

En esta Nueva España hay muchas doncellas, hijas de personas muy honradas. Es necesario que V. Sa tenga especial cuidado de las favorecer en sus casamientos, porque esto importa mucho a la perpetuidad de la tierra, y por razón de esto está muy apretada. En todo lo que yo podía favorecer los casamientos lo hacía, porque demás de ver que así convenía y era servicio de Dios Nuestro Señor, S. M. me lo tenía encargado; y para animar que se casasen les prometía y daba a algunas personas corregimientos y ayuda de costa. Será necesario que V. $S^{a}$ haga lo mismo. ${ }^{28}$

Teoricamente, esse encargo relacionava-se com preceitos sociais e de gênero derivados do sistema hierárquico e patriarcal imperante na Nova Espanha do século XVI. A mulher solteira era considerada um elemento social perigoso, e, quando se tratava de uma dama de boa família, imperava a preservação de sua honra. Na prática, essa proteção relacionou-se com o costume de os vice-reis casarem seus criados com as criollas mais ricas do reino, nomeadamente com as encomenderas. A Coroa tratou novamente de frear esse costume, proibindo-o explicitamente, e a partir de 1596 passou a recordar nas Instrucciones dadas aos sucessivos vice-reis os males que derivavam de seu incumprimento:

Porque una de las mayores quejas de los vecinos y que causa más descontento en la tierra es la poca libertad que las encomenderas tienen en sus casamientos. Porque sucediendo alguna en algún buen repartimiento, los virreyes las casan con criados suyos o ellos los procuran y solicitan, de manera que con los medios que ponen y principalmente con el favor que para ello les dan los virreyes les alcanza. Lo cual es causa de muchos repartimientos y de los mejores y hallen y estén al presente en personas que no han servido, con gran sentimiento, quejas y descontento de los que habiendo servido y teniéndolo por muy merecido, se quedan sin ello. Y porque no es justo ni

\footnotetext{
${ }^{28}$ VILLAR, Ernesto de la Torre. Instrucciones y memorias de los virreyes novohispanos. México: Porrúa, 1991, p. 110.
} 
conveniente que pase esto delante estaréis advertidos de no embarazaros y tratar de dichos casamientos sino que los dejéis correr con la libertad que es justo y necesario. ${ }^{29}$

Atendendo às Leis de Índias, os vice-reis foram proibidos de favorecer com ofícios ou aprovechamientos seus parentes e criados. Disso se deduz que a Coroa foi consciente do risco acometido por tal situação e tratou de limitá-lo. ${ }^{30}$ Ainda assim, a realidade esteve pautada pelo permanente incumprimento desses termos, o que conduzia à aplicação de sucessivas multas aos funcionários. Tal situação culminou, em 1678, com a promulgação de uma Real Cédula pela qual se privou os vice-reis da faculdade de fornecer corregimientos e alcaldias mayores. No entanto, era uma das atribuições fundamentais para garantir o reconhecimento da autoridade vice-reinal, e, passados apenas dois anos, restituiu-se a situação anterior. ${ }^{31}$

Apesar das travas legais, peninsulares e criollos frequentemente terminavam unidos por casamentos de interesse. As numerosas dispensas para esse tipo de matrimônios que se solicitavam desde o vice-reino, muitas delas oferecendo em troca o pagamento de uma quantia importante à Coroa, sugerem que as criollas puderam servir como instrumento de união entre os dois grupos. No entanto, esse costume também gerou um grande ressentimento entre todos os criollos que ficaram afastados do acesso às herdeiras das maiores fortunas do Reino. Gemelli Careri, viajante italiano que percorreu a Nova Espanha no século XVII, referiu-se a essa concorrência:

[As criollas] son hermosísimas y muy bien plantadas. Tienen mucha inclinación por los europeos (a quienes llaman gachupines) y con ellos (aunque muy pobres) más a gusto se casan que con sus ciudadanos llamados criollos, aunque ricos; viendo a estos amantes de las mulatas, de las cuales han mamado, junto con la leche, las malas costumbres. De ello se sigue que los criollos odian de tal manera a los europeos, que al pasar alguno por las calles, le hacen burla, avisándose de tienda en tienda con la expresión: él es. Y por eso, algunas veces, los españoles encolerizándose, les han disparado pistoletazos.

\footnotetext{
${ }^{29}$ Ibid., p. 260 e 357.

${ }^{30}$ Ley XXVII, Título II, Libro III y Ley XXXII, Título III, Libro III, In: PIDAL, Raúl Menéndez. Recopilación de las leyes de los reinos de Indias. Madrid: Cultura Hispánica, 1973.

${ }^{31}$ CAÑEQUE, Alejandro. De parientes, criados y gracias. Cultura del don y poder en el México colonial, siglos XVI-XVII. Histórica, Lima, vol. 29, n. 1, 2005, p. 37-38.
} 
En fin, ha llegado a tal punto esta competencia, que odian a sus mismos padres porque son europeos. ${ }^{32}$

Nessas uniões matrimoniais, os peninsulares aportavam sua posição no cortejo vice-reinal, a possibilidade de participar na administração Real ou da iniciativa empresarial associada ao comércio, além de contribuir com a "limpeza do sangue" (entendida na América como a ausência de sangue negro). Paralelamente, as criollas tinham o prestígio de formar parte das linhagens dos conquistadores, sua riqueza associada à exploração do novo continente ou a influência local. ${ }^{33}$ Como prova evidente de seu apoio, em muitas ocasiões o vice-rei apadrinhava e premiava diretamente esses casamentos.

A adesão local ao plano administrativo do vice-rei dependia da habilidade dos governantes de integrar as principais famílias criollas na distribuição de poder e de recursos do Reino, tanto por concessão direta como por matrimônio. Dessa forma, estudar o destino que os principais dotes seguiram e seu papel na forja de alianças matrimoniais deve nos ajudar a entender como se organizavam os "grupos de pressão" na Nova Espanha.

As vice-rainhas também pertenciam à nobreza (em alguns casos inclusive superando seus maridos em títulos) e, portanto, estavam igualmente obrigadas a entrar no jogo político da concessão de benefícios a suas criadas. As damas de companhia que a vice-rainha levava desde a Espanha ao Novo Mundo eram, em sua maioria, solteiras. Elas tinham esperança de, durante seu serviço, conhecer um homem de boa posição com quem se unir em matrimônio ou, em seu defeito, receber alguma mercê como presente de casamento, às vezes materializada num cargo para o futuro marido. Sendo assim, em 1696 a Condesa de Galve queixou-se amarguradamente ao Marquês de Távara por voltar sozinha à Espanha. Apesar de ter chegado acompanhada de 10 dueñas y 5 criadas: "pues hay gran prisa a casarse, se casó una mujer moza... y una de la cámara y están para casarse otras dos... y harto lo siento porque se quedan por acá" ${ }^{34}$

Novamente, criollos e peninsulares terminam entrelaçados, nesse caso pelo casamento de espanholas com novo-hispanos. Assim, muitas das donzelas que atravessaram o Atlântico com as vice-rainhas passaram a formar parte da aristocracia local. O fato de a Real Cédula - pela qual se autorizava

\footnotetext{
32 CARERI, Giovanni Francesco Gemelli. Viaje a la Nueva España. Ciudad de México: Unam, 1976, p. 22.

33 ZAPATERO, Alberto Baena. Una nueva perspectiva sobre la identidad criolla: la incorporación de las mujeres (s. XVI-XVII). Arenal: Revista de Historia de las mujeres, Granada, vol. 18, n. 2, 2011, p. 433-460.

34 Citado por ESCAMILLA, Iván. La corte de los virreyes. In: RUBIAL, Antonio (ed.). Historia de la vida cotidiana en México, vol. 2. Ciudad de México: Fondo de Cultura Económica, 2005, p. 383.
} 
a viagem da Marquesa de Cadereyta - especificar que nenhuma de suas 24 criadas fosse casada, fomenta questões acerca das intenções da Coroa. ${ }^{35}$ À margem da política Real, que protegia a instituição da família, a preferência por criadas solteiras poderia estar relacionada com o desejo de estabelecer uma rede de patrocínios que tivessem como eixo a vice-rainha. O casamento de peninsulares com membros das linhagens criollas mais importantes assegurava uma série de adesões que reforçariam a posição dos governantes.

Já se apontou que, quando as criadas eram casadas, viajavam com suas famílias, abrindo vias de relação alternativas com a sociedade local, a partir do matrimônio de um dos filhos com algum jovem criollo ou criolla. Assim, por exemplo, Teresa Ortiz de Heredia, valenciana filha de Catalina del Rio, dama de companhia da vice-rainha, casou-se com Alonso Muñoz Castiblanque, capitão da guarda do vice-rei Conde de Paredes, filho do regidor da Cidade do México e contador maior do Tribunal do Santo Ofício. ${ }^{36}$ Enquanto Brígida de España, natural de Málaga e filha de Gertrudis Vélez, "caballera de la virreina", entregou carta de dote para se casar com José de Luaces. ${ }^{37}$

Para complicar ainda mais o difícil equilíbrio de relações entre os governantes e a elite local, as vice-rainhas também tinham a possibilidade de se exceder nos benefícios concedidos a seus favoritos ou de aproveitar sua posição privilegiada para enriquecerem pessoalmente. Essas circunstâncias tinham um efeito adverso, provocando o desapego dos criollos e causando graves problemas a seus maridos. Em 1619, a Coroa espanhola promulgou uma Real Cédula com o intuito de evitar o reparto de ofícios entre os parentes e familiares dos vice-reis. Entre os motivos expostos, salientavam-se os prejuízos que derivavam de patrocinar o círculo das vice-rainhas: "los parentescos de las mujeres de los tales ministros y parientes de ellas suelen ser más molestos y de mayor perjuicio al gobierno público que los deudos de los mismos maridos".38

Um dos casos mais evidentes em que se ultrapassou o modelo de modéstia e recato que se esperava de uma dama nobre foi protagonizado por Mariana Isabel de Leiva y Mendoza, Marquesa de Leiva e Condessa de Baños, estudado recentemente por Isabel Arenas. No Juicio de Residencia realizado a seu esposo, denunciou-se como a vice-rainha cobrava grandes quantias de

\footnotetext{
35 AGI, Indiferente, 453, L.A18, f.49. Real Cédula a la Casa de la Contratación para que dejen pasar a la Marquesa de Cadereyta, llevando 24 mujeres de servicio. Madrid, 19 abr. 1635.

${ }^{36}$ AGNDF, escrivão José de Anaya (6), folio 42, Carta de dote: 29 mar. 1687.

37 AGNDF, escrivão José de Anaya (6), folio 4, Carta de dote: 31 jan. 1693.

${ }^{38}$ Citado por CAÑEQUE, Alejandro. De parientes, criados y gracias. Cultura del don y poder en el México colonial, siglos XVI-XVII. Histórica, Lima, vol. 29, n. 1, 2005, p. 28.
} 
dinheiro ou presentes a quem quisesse obter algum cargo, participando ainda do lucrativo comércio com as Filipinas, aproveitando-se de numerosos corregimientos e alcaldías mayores que concedia a seus criados. ${ }^{39}$

As novas pesquisas fazem questão de ver a corte como um "ponto de contato" entre o príncipe e seus súditos ou, nas palavras de Antonio Rubial, "una cancha donde se practicaba el juego del regateo político". ${ }^{40}$ Dentro da vida política do reino, pesava mais a relação com os vice-reis que o princípio de prelação estabelecido pela legislação americana, segundo o qual se devia antepor aos descendentes de conquistadores e primeiros povoadores no momento de conceder mercês.

Fazer parte do entorno dos vice-reis foi fundamental para os criollos, já que isso lhes permitia estar no lugar onde se tomavam muitas decisões que lhes afetavam. Esse jogo político era um dos motivos que justificavam a existência da vida cortesã, dado que qualquer atividade supunha uma desculpa perfeita para se aproximar da família vice-reinal e ganhar sua confiança. Segundo essa ideia, para o historiador Jacques Lafaye, os criollos estariam divididos em dois grupos: os mais ricos ou influentes, que tinham estreita relação com a corte, e os outros. ${ }^{41}$ Os primeiros encontravam-se em condições de estabelecer alianças com os cortesãos peninsulares, eram leais a um sistema no qual ocupavam um lugar privilegiado e se encontravam relativamente satisfeitos com sua sorte. Enquanto o resto, orgulhosos, mas empobrecidos e frustrados, aspiravam a melhorar sua situação, ocupando os privilégios dos "advenedizos". ${ }^{42}$ Portanto, o acesso à corte determinava a posição política de muitas famílias novo-hispanas, confirmando a tese de que as redes clientelares tecidas pelos vice-reis e suas esposas poderiam ajudar a cimentar o poder da Coroa na América. ${ }^{43}$ Aqueles que ficavam à margem da corte observavam com ressentimento como eram excluídos do reparto dos

\footnotetext{
39 FRUTOS, Isabel Arenas. ¿Sólo una virreina consorte de la Nueva España? 1660-1664: la II Marquesa de Leiva y II Condesa de Baños. Anuario de Estudios Americanos, Sevilla, vol. 67, n. 2, 2010, p. 551-575.

${ }^{40}$ ELTON, Geoffrey Rudolph. Tudor government: the points of contact. Transactions of the Royal Historical Society, London, vol. 26, 1976, p. 211-228; RUBIAL, Antonio. Monjas, cortesanos y plebeyos: la vida cotidiana en la época de Sor Juana. Ciudad de México: Taurus, 2005, p. 121.

${ }^{41}$ LAFAYE, Jacques. Quetzalcóatl y Guadalupe: la formación de la conciencia nacional en México. Ciudad de México: Fondo de Cultura Económica, 1999, p. 46.

${ }^{42}$ Advenedizos eram peninsulares recém-chegados na América que não tinham participado na conquista nem na sua posterior colonização (Ibid., p. 43-48).

43 CAÑEQUE, Alejandro. Cultura vicerregia y Estado colonial. Una aproximación crítica al estudio de la historia política de la Nueva España. Historia Mexicana, Fuentes del Pedregal, vol. LI, n. 1, p. 5-57, 2001.
} 
cargos do reino. Um desses criollos foi Dorantes de Carranza, que reivindicou o direito das famílias dos conquistadores e primeiros povoadores do México às melhores mercês e resumiu em versos o ódio por aqueles cortesãos a quem eram outorgadas sem sequer as merecerem:

\author{
Malditos seáis de Dios, \\ Embusteros charlatanes \\ ¿Entendéis que acá no hay hombres, \\ servicios ni calidades? \\ Mil años viva el marqués, \\ Y quien se lo aconsejare, \\ Si cuando pedís la lanza \\ Con ella os alanceare. ${ }^{44}$
}

Entre as estratégias que os novo-hispanos utilizaram para se aproximar do poder, muitos optaram por conquistar a simpatia da vice-rainha, sabedores do peso que tinha nas decisões de seu esposo. Segundo o sistema patriarcal imperante na época, as mulheres não possuíam o direito de ocupar cargos públicos, mas podiam exercer sua influência na política informal da corte. Muitos criollos sabiam disso e tentaram utilizá-la em seu benefício. Em 1703, o tesoureiro da Casa da Moeda da Cidade do México, Francisco de Medina y Picazo, tentou agradar a vice-rainha oferecendo-lhe um barco para que fosse a Ixtacalco "de doce varas de largo, cuatro de ancho y tres de alto, muy dorado, y con diez remeros vestidos de lampazos de China, que costó más 1000 pesos". ${ }^{45}$ Além disso, celebrou uma comédia em honra do casal de vice-reis e ofereceu "a las damas cien pesos a cada una". ${ }^{46}$

Houve também situações incômodas, nas quais o cortesão foi além do que devia em seu desejo de agradar a vice-rainha. Foi o caso de Francisco de Córdoba, comerciante e contador maior do tribunal de contas da Cidade do México, que em 1655 convidou a Duquesa de Alburquerque e sua filha para assistirem à procissão de Corpus Christi da sacada de sua casa, oferecendolhes um custoso almoço de doces. Essa visita chamou a atenção da cidade, e o vice-rei se considerou desonrado. Dias depois, na frente de sua mulher, golpeou o responsável tão fortemente "que lo bañó en sangre y derribó un diente". ${ }^{4}$

\footnotetext{
${ }^{44}$ DORANTES DE CARRANZA, Baltasar. Sumaria relación de las cosas de Nueva España. Ciudad de México: Porrúa, 1987, p. 135-138.

${ }^{45}$ ROBLES, Antonio de. Diario de sucesos notables, vol. 2. Ciudad de México: Porrúa, 1946, p. 270.

${ }^{46}$ Id., Diario de sucesos notables, vol. 3. Ciudad de México: Porrúa, 1946, p. 265.

${ }^{47}$ GUIJO, Gregorio María de. Diario, 1648-1664, vol. 2. Ciudad de México: Porrúa, 1953, p. 20.
} 
Parece que o contador não mudou de estratégia, já que algum tempo depois, no Corpus Christi de 1669, voltou a convidar outra vice-rainha a sua sacada, a Marquesa de Mancera. ${ }^{48}$ Se considerarmos as notícias registradas pelo cronista Gregorio Martín de Guijo no seu Diario, é possível supor que a vice-rainha não seria fácil de influenciar, já que, segundo ele, "cuando le iban a pedir alguna cosa se enfadaba y decía: vayan al rollo de Tepeaca" ${ }^{49}$

Dado que não se tratava de uma função formal, a influência das vice-rainhas dependia tanto de seu caráter quanto da personalidade de seus maridos. Dessa forma, os exemplos variam entre aquelas que exerciam seu poder com autoridade e sem dissímulo, até outras mais discretas, que se preocupavam só com seu círculo mais próximo ou por algum convento de sua preferência. No entanto, o mando político e a atividade econômica se consideravam próprias do espaço público e, portanto, dos homens. As mulheres que agiam sem tomar em conta o juízo social de suas ações se arriscavam a ser chamadas de "dominantes". Em 1587, o frade Alonso de San Juan acusava a vice-rainha Blanca de Velasco de ser uma mulher "de ligeras costumbres y de carácter muy dominante y altivo", por visitar conventos de ambos os sexos e não ocultar seu poder sobre as decisões do reino. ${ }^{50}$

Em 1648, o bispo Juan de Palafox denunciou a Condessa de Salvatierra de interferir contra suas reformas na corte, ${ }^{51}$ enquanto a Marquesa de Leiva provocaria um conflito entre o vice-rei e o cabildo eclesiástico por causa da procissão do Corpus Christi de 1662. Devido ao delicado estado de saúde da vice-rainha, o percurso do evento foi alterado para passar pela praça maior, e, assim, ela poderia assisti-lo da varanda do palácio. ${ }^{52}$ A Marquesa era muito criticada por seu caráter ambicioso, e o oidor da Cidade do México, Ginés Morote, assegurava numa carta ao rei que muitos desejavam sua morte. ${ }^{53}$ Ela era considerada a culpada das más políticas do reino, enquanto o bispo de

\footnotetext{
${ }^{48}$ AGI, México, 44, N.15. Testimonio de las cortesías que el día de la octava del corpus 12 de junio de 1670 tuvieron el virrey y el arzobispo de México. México, 17 jul. 1670.

49 ROBLES, Antonio de. op. cit, p. 147.

50 ARIZPE, Artemio de Valle. Virreyes y virreinas de la Nueva España. México: Porrúa, 2000, p. 14.

51 Juan de Palafox afirmaria que "una señora en Palacio, y tan sagaz, como mi señora la condesa de Salvatierra, todo lo trasmina". PALAFOX Y MENDOZA, Juan. Cartas del venerable siervo de Dios D. Juan de Palafox y Mendoza, Obispo de la Puebla de los Angeles, a el Rmo. Padre Andres de Rada. Madrid: Imprensa de don Manuel Martin, 1768, p. 72.

${ }^{52} \mathrm{O}$ vice-rei foi denunciado e condenado a pagar uma multa de 12 mil ducados. FRUTOS, Isabel Arenas. ¿Sólo una virreina consorte de la Nueva España? 1660-1664: la II Marquesa de Leiva y II Condesa de Baños. Anuario de Estudios Americanos, Sevilla, vol. 67, n. 2, 2010, p. 558-559.

53 AGI, México, 77, R. 2, N. 27, f. 2. Carta de Ginés Morote, oidor de la Audiencia de México. México, 3 jul. 1663.
} 
Puebla, Diego Osorio de Escobar, a acusaria de interferir na administração de justiça, alegando que "si no es a gusto de la virreina no tiene lugar, ni se atreven los oidores, por las molestias que les hacen, a votar libremente" ${ }^{54}$

É válido frisar que nesse período não existia diferenciação clara entre a vida privada e a vida pública dos vice-reis, unindo sua condição moral à fortuna do reino e ao respeito de seus súditos.

A historiografia de gênero mostra que houve uma tensão nas mulheres entre a submissão ao modelo patriarcal teórico e os desvios da norma, embora os estudos deem mais atenção ao segundo caso. ${ }^{55}$ Steve Stern assinala que as mulheres que transgrediam os preceitos de gênero se situavam nos "limites ou nas margens" do corpo social aceite, apresentando-se como "figuras perigosas, poderosas ou subversivas" ${ }^{156} \mathrm{O}$ controle sobre a vida das espanholas ou criollas ricas era maior por serem elas as detentoras da honra familiar. Sendo assim, uma vice-rainha que não se ativesse ao comportamento que se esperava de uma dama prudente e discreta supunha um exemplo perigoso para o resto da sociedade. No entanto, esses desafios práticos à autoridade masculina foram atitudes individuais que não puseram em causa as bases patriarcais da sociedade..$^{57}$

Ainda é necessário saber mais sobre as relações informais e de patronato dos vice-reis, além da formação e confronto de facções dentro da corte. Com a informação atual, é possível intuir que os objetivos das vice-rainhas e de seus agregados nem sempre coincidiam com os de seus maridos. Segundo Manuel Rivero Rodríguez, os cortejos das vice-rainhas funcionavam de maneira autônoma e cobriam possíveis vazios ou omissões. Foi o que aconteceu com as rainhas na Europa, que "facilitavam vias alternativas de aceso ao poder ou à eminência social para pessoas, grupos ou corporações excluídas ou sem comunicação com o círculo da Casa e corte dos vice-reis" ${ }^{58}$

Essa situação se destacou no caso de Ignacia Cruzat e Góngora, filha do antigo governador de Filipinas. O grande dote que recebeu para seu casa-

${ }^{54}$ AGI, México, 77, R. 2, N. 24, f. 3. Carta del obispo de Puebla. México, 11 jun. 1663.

55 STERN, Steve J. La historia secreta del género: mujeres, hombres y poder en México en las postrimerías del periodo colonial. Ciudad de México: Fondo de Cultura Económica, 1999, p. 27-70.

${ }^{56}$ loc. cit.

57 loc. cit.

58 Tradução do autor. RODRIGUES, Manuel Rivero. Como reinas: el virreinato en femenino (apuntes sobre la Casa y Corte de las virreinas). In: MILLÁN, José María Martínez E LOURENÇO, Paula Marçal (ed.). Las relaciones discretas entre las Monarquías Hispana y Portuguesa: las Casas de las Reinas (siglos XV-XIX), vol. 2. Madrid: Polifemo, 2009, p. 807. 
mento provocou um conflito enorme entre o arcebispo e o vice-rei Duque de Alburquerque, ambos interessados em apresentar um noivo de seu círculo. Em seu Diario, Antonio Robles registrou como a Duquesa Juana de la Cerda Aragón tentou mediar ambos e convenceu o arcebispo a ir ao palácio ter uma entrevista com seu esposo. ${ }^{59}$ No entanto, o assunto não foi resolvido, e a vice-rainha decidiu apoiar o candidato do religioso, Domingo Sánchez de Tagle, ameaçando o Duque com um divórcio. ${ }^{60}$

\section{A vida na corte e o teatro social na Nova Espanha}

A grande atividade social protagonizada pelos governantes e suas esposas na Nova Espanha contrasta com a "inacessibilidade" ou "afastamento" do poder praticado pela dinastia Habsburgo em Madrid. Na América, as aparições públicas do casal como lembrança simbólica intensificavam a presença da Coroa. ${ }^{61}$ Em todas as ocasiões importantes, os vice-reis compareciam com seus criados e se envolviam com a elite criolla.

À margem das festas religiosas e políticas a que os vice-reis obrigatoriamente assistiam, existia na Nova Espanha um conjunto de atividades lúdicas que Bernardo de Balbuena definiu como "ocasiones de contento". ${ }^{62} \mathrm{O}$ poeta lembrou com orgulho as numerosas festas, jogos, saraus, bailes, passeios, concertos, corridas, banquetes, comédias ou touradas que se celebravam na Cidade do México no início do século XVII, com grande gasto e assistência de pessoas.

Deixando de lado a imagem frívola que se construiu sobre os cortesãos em épocas posteriores, Antonio Álvarez Ossorio Alvariño anima a olhar para essas festas como "um dos principais eixos de socialização da corte". ${ }^{3}$ Era precisamente durante essas celebrações que as oligarquias locais tinham acesso ao entorno dos vice-reis e se estabeleciam relações econômicas, políticas ou amorosas no topo da sociedade. Além disso, era o momento em que

\footnotetext{
59 ROBLES, Antonio de. Diario de sucesos notables (1665-1703), vol. 3. Ciudad de México: Porrúa, 1946, p. 274. AGI, México, 642. Expediente sobre los incidentes ocurridos con motivo de la celebración del matrimonio de don Domingo Ruiz de Tagle y doña Ignacia de Cruzat y Góngora. México, 1703-1709.

${ }^{60}$ OBREGÓN, Luís González. México viejo. Ciudad de México: Patria, 1966, p. 384-386.

${ }^{61}$ CAÑEQUE, Alejandro. De sillas y almohadones o de la naturaleza ritual del poder en la Nueva España de los siglos XVI y XVII. Revista de Indias, Madrid, vol. LXIV, n. 232, 2004, p. 632.

${ }^{62}$ TORQUEMADA, Fray Juan de. Monarquía indiana. Ciudad de México: Unam, 1975, p. 358.

${ }^{63}$ ALVARIÑO, Antonio Álvarez-Ossorio. La Corte: un espacio abierto para la historia social. In: CASTILLO, Santiago (ed.). La historia social en España: actualidad y perspectivas. Zaragoza: Siglo XXI, 1991, p. 247-260.
} 
as elites do vice-reino representavam publicamente sua condição privilegiada, mostrando todos os indicativos de status.

Embora ultrapasse os objetivos deste artigo, deve-se salientar a significação política desses eventos na Nova Espanha. Para a Coroa era uma forma de manter as elites criollas contentes, enquanto para as oligarquias locais se tratava de uma maneira de reafirmar a posição social que ocupavam e reivindicar sua importância dentro da monarquia. ${ }^{64} \mathrm{Na}$ cultura da época, considerava-se que a grandeza de um reino era igual ao número de celebrações e a seus gastos. Por esse motivo, para Balbuena, a frequência e a riqueza desses eventos era de tais proporções que o Novo Mundo não teria nada de invejar ao Velho. ${ }^{65}$

As vice-rainhas, longe de permanecerem fechadas em palácios, como exigia o modelo moral católico, mostravam-se em numerosos atos não oficiais. As damas constituíam o centro da vida social na corte, tanto que, segundo Antonio Rubial, quando o cargo de vice-rei era ocupado por um religioso, a atividade cortesã praticamente desparecia. ${ }^{66}$ À diferença do que acontecia com a maioria das mulheres, ocultas detrás de masculinos genéricos como o "povo" ou "a cidade", a relevância política e social das vice-rainhas permitiu que os cronistas da época registrassem sua presença pública. Assim, essas mulheres e seus cortejos participavam de festas na cidade, como bailes, touradas, ou obras de teatro, visitando lugares de recreio, como a Alameda e Chapultepec, ou indo para canais próximos, como os de Jamaica ou La Viga.

Na Nova Espanha, como na Europa, todas essas atividades se desenvolviam segundo um complexo sistema social, que abarcava formas de comportamento, etiqueta e valores aristocráticos. A presença das damas era imprescindível, já que, como lembra Castiglione, não podia existir um cortesão "que tenga gracia, o sea hombre de gusto o esforzado, o haga jamás buen hecho, sino movido y levantado con la conversación y amor de ellas" ${ }^{67}$ Portanto, o ideal aristocrático só seria atingido depois de uma cuidada educação e com sua contraparte feminina, a qual também tinha suas próprias normas de comportamento.

\footnotetext{
${ }^{64}$ ZAPATERO, Alberto Baena. Mujeres novohispanas e identidad criolla (siglos XVI y XVII). Alcalá de Henares: Ayuntamiento de Alcalá de Henares, 2009, p. 49-74.

${ }^{65}$ BALBUENA, Bernardo de. La grandeza mexicana y compendio apologético en alabanza de la poesía. Ciudad de México: Porrúa, 1975, p. 89-93.

${ }^{66}$ RUBIAL, Antonio. Las virreinas novohispanas: presencias y ausencias. Estudios de Historia Novohispana, Ciudad de México, vol. 50, 2014, p. 3-44.

${ }^{67}$ CASTIGLIONE, Baldassare. El cortesano. Madrid: Espasa-Calpe, 1984, p. 231.
} 
A falta de uma nobreza titulada na América fez a elite criolla depender especialmente da representação pública que a corte vice-reinal proporcionava. ${ }^{68}$ Só assim se entendem as palavras de Arias de Villalobos:

Pues si a la corte hace el real ornato,

De ornato real en nuestra Corte hay sobra:

Coches, braveza, estados, aparato;

Que aunque en títulos falta, en esto sobra. ${ }^{69}$

Novamente, Bernardo de Balbuena, sempre atento a exaltar as qualidades do México, louvou o comportamento de suas damas como mais uma prova das virtudes do reino:

Damas de la beldad misma retrato,

afables, cortesanas y discretas,

de grave honestidad, punto y recato. ${ }^{70}$

Enquanto Sor Juana Inés de la Cruz quis deixar claro que a corte local se comportava segundo os mesmos códigos sociais da Europa, respeitando o que a Recopilação de Leis de Índias de 1680 agrupou sob o título "precedencias, ceremonias y cortesías":

Oy que de la Damería

se ajaban las preeminencias

(que en Méjico también hay

su poquito de etiqueta). ${ }^{71}$

A educação aristocrática era imprescindível para a vida na alta sociedade e se as famílias criollas queriam ter acesso à corte estavam obrigadas a conhecê-la. Uma boa cortesã devia saber bailar, tocar um instrumento musical, falar corretamente, cantar, etc. Gemelli Careri, por exemplo, deixou testemunho de como no passeio do canal de Jamaica homens e mulheres faziam

${ }^{68}$ BÜSCHGES, Christian. La corte virreinal en la América Hispánica durante la época colonial (periodo Habsburgo). In: CONGRESSO INTERNACIONAL DE AHILA: AMÉRICA LATINA: OUTRO OCCIDENTE? DEBATES DO FINAL DO MILENIO, 12., 2001, Porto. Atas... Porto: Centro Leonardo Coimbra, Faculdade de Letras da Universidade do Porto, 2001, p. 131-140.

${ }^{69}$ VILLALOBOS, Arias de. "México en 1623" In: GARCÍA, Genaro. Documentos inéditos o muy raros para la historia de México. México: Porrúa, 1975, p. 367.

${ }^{70}$ BALBUENA, Bernardo de. La grandeza mexicana y compendio apologético en alabanza de la poesía. México: Porrúa, 1975, p. 116-117.

${ }^{71}$ CRUZ, Sor Juana Inés de la. Obras completas. México: Fondo de Cultura Económica, 1976. p. 97. 
concorrências de canto sobre as barcas. ${ }^{72}$ Se os criollos se queriam assimilar às aristocracias europeias também deviam gastar uma grande suma de dinheiro no vestido e adorno dos seus corpos, acompanhar-se por criados e pessoal de serviço. Nas pinturas dos biombos mexicanos dos séculos XVII e XVIII achamos as criollas exibindo todos os indicadores de poder, cantando, tocando instrumentos musicais, comendo doces, jogando cartas, passeando com as suas escravas, mas sobre tudo, participando do jogo amoroso cortesão, o galanteio. Estas pinturas demonstram que os seus donos tinham o mesmo desejo que Balbuena ou Sor Juana de deixar registro da esplendida vida cortesã do reino.

\section{Considerações finais}

Da análise do papel das vice-rainhas e suas damas de companhia, deduzimos a impossibilidade de entender o funcionamento da corte e da sociedade novo-hispanas em toda sua complexidade sem considerar as mulheres. Conforme a política da época, os vice-reis estabeleceram um conjunto de relações pessoais como estratégia para assegurar o controle do território. De acordo com essa suposição, as vice-rainhas receberam a missão de colaborar com os interesses reais de duas formas: em primeiro lugar, fomentando os laços com a elite local ao incorporar as damas criollas a seus cortejos; e, em segundo, conseguindo novas lealdades no reino ao beneficiar as alianças de suas criadas peninsulares com membros de famílias locais. As relações pessoais das vice-rainhas tornavam-nas intermediárias em certas crises políticas, facilitando a comunicação entre os diferentes atores sociais. É interessante que, quando o acordo não era possível, as vice-rainhas nem sempre optavam por apoiar seus esposos.

Até o momento, sabe-se pouco sobre a rede social que dependia da primeira dama do reino (familiares, criadas, deudos), o que sugere a necessidade estudos micro-históricos que reconstruam sua vida e forneçam informação sobre sua participação na política de alianças no topo da sociedade. Para atingir esse objetivo, deve-se averiguar quando e com quem as mulheres do cortejo se casaram, que mercês elas ou seus esposos receberam, e o que se esperava em troca desses favores.

\footnotetext{
72 "Después de comer fui de paseo al canal de Jamaica, que es el Posilipo de México. Allí se pasea en canoas o barcas (si se quiere también por tierra), con gran número de músicos y de cantores, los cuales compiten (hombres $y$ mujeres) para hacer apreciar la perfección de su canto". CARERI, Giovanni Francesco Gemelli. Viaje a la Nueva España. Ciudad de México: Unam, 1976.
} 
Os estudos acerca do patronato auxiliado pela vice-rainha exemplificam como na Idade Moderna a linha que dividia a vida pública da privada não foi tão estrita como em períodos posteriores, comprovando que em determinadas situações as relações pessoais facilitavam ou suplantavam as vias burocráticas oficiais. ${ }^{73}$

Essas mulheres não desfrutavam do atributo de serem transmissoras do sangue Real nem contavam com a possibilidade de herdar o poder com a morte de seus esposos. Sua repercussão política derivava exclusivamente do fato de serem esposas do vice-rei. No entanto, as fontes demonstram o peso que muitas delas tiveram na tomada de decisões e nas estratégias que desenvolveram em torno do exercício do poder indireto. Fica aberta a questão: sem o apoio concedido pelo cortejo e pelas alianças conquistadas pelas vice-rainhas - podendo manter inclusive posições divergentes das de seus maridos -, sua influência sobre a sociedade teria sido tão considerável?

A liderança do vice-rei dependia também de seu carisma, mas o comportamento de sua família poderia comprometer o respeito dos súditos. Se alguma vice-rainha utilizasse sua influência política sem a dissimulação que se esperava, ou se excedesse seus desejos por enriquecer-se e beneficiar seus achegados, poderia criar um clima de desafeição com os governantes. Dessa forma, essas damas tinham que manter um difícil equilíbrio entre o ideal cristão de mulher recolhida e seu papel social como protagonistas das numerosas atividades da vida cortesã.

Para as famílias criollas enriquecidas, a corte da Cidade do México era o lugar apropriado para que seus membros aprendessem a se comportar e pusessem em prática seu papel como "nobres americanos". Assim, as vice-rainhas e suas criadas traziam novas modas ou valores que chegavam da Europa, criando uma ligação cultural entre Madrid e México.

Por último, a presença das vice-rainhas na vida pública do reino acaba com a ideia simplificadora de que elas só foram esposas passivas, que se limitaram a reproduzir o modelo teórico patriarcal que lhes foi atribuído. Futuros trabalhos deverão desenvolver muitas das ideias propostas neste artículo e fornecer dados novos, ajudando a recuperar o papel dessas mulheres e a criar uma visão mais ampla e integradora da corte mexicana.

\footnotetext{
${ }_{73}$ BÜSCHGES, Christian. La corte virreinal en la América Hispánica durante la época colonial (periodo Habsburgo). In: CONGRESSO INTERNACIONAL DE AHILA: AMÉRICA LATINA: OUTRO OCCIDENTE? DEBATES DO FINAL DO MILENIO, 12., 2001, Porto. Atas... Porto: Centro Leonardo Coimbra, Faculdade de Letras da Universidade do Porto, 2001, p. 131-140.
} 


\section{Siglas e abreviaturas dos arquivos consultados}

AGI: Archivo General de Indias, Sevilha;

AGNDF: Archivo General de Notarías del Distrito Federal, Fondos Antiguos.

\section{Referências bibliográficas}

ALVARIÑO, Antonio Álvarez-Ossorio. La Corte: un espacio abierto para la historia social. In: CASTILLO, Santiago (ed.). La historia social en España: actualidad y perspectivas. Zaragoza: Siglo XXI, 1991, p. 247-260.

ARANCIVIA, Eduardo Torres. Corte de virreyes: el entorno del poder en el Perú del siglo XVII. Lima: Pontificia Universidad Católica del Perú, 2006.

ARIZPE, Artemio de Valle. Virreyes y virreinas de la Nueva España. Ciudad de México: Porrúa, 2000.

Virreyes y virreinas de la Nueva España: tradiciones, leyendas y sucedidos del México virreinal, vol. 2. Ciudad de México: Porrúa, 2000.

BALBUENA, Bernardo de. La grandeza mexicana y compendio apologético en alabanza de la poesía. Ciudad de México: Porrúa, 1975.

BÜSCHGES, Christian. Del criado al valido: el padronazgo de los virreyes de Nápoles y Nueva España (primera mitad del siglo XVII). In: CANTÜ, Francesca (ed.). Las cortes virreinales de la Monarquía española: América e Italia. Roma: Viella Libreria Editrice, 2008, p. 157-181.

. La corte virreinal como espacio político: el gobierno de los virreyes de la América hispánica entre monarquía, élites locales y casa mobiliaria. In: CARDIM, Pedro \& PALOS, Joan-Lluís (ed.). El mundo de los virreyes en las monarquías de España y Portugal. Madrid: Iberoamericana, 2012, p. 319-344.

. La corte virreinal en la América Hispánica durante la época colonial (periodo Habsburgo). In: CONGRESSO INTERNACIONAL DE AHILA: AMÉRICA LATINA: OUTRO OCCIDENTE? DEBATES DO FINAL DO MILENIO, 12., 2001, Porto. Atas... Porto: Centro Leonardo Coimbra, Faculdade de Letras da Universidade do Porto, 2001, p. 131-140.

BRUNKE, José de la Puente. Monarquía, gobierno virreinal y élites: el Perú en el siglo XVII. In: CANTÚ, Francesca (ed.). Las cortes virreinales de la Monarquía española: América e Italia. Roma: Viella Librería, 2008, p. 103-118.

CANTÙ, Francesca (ed.). Las cortes virreinales de la Monarquía española: América e Italia. Roma: Viella Libreria Editrice, 2008.

CAÑEQUE, Alejandro. Cultura vicerregia y Estado colonial. Una aproximación crítica al estudio de la historia política de la Nueva España. Historia Mexicana, Fuentes del Pedregal, vol. LI, n. 1, 2001, p. 5-57.

De parientes, criados y gracias: cultura del don y poder en el México colonial, siglos XVI-XVII. Histórica, Lima, vol. 29, n. 1, 2005, p. 3-42.

. De sillas y almohadones o de la naturaleza ritual del poder en la Nueva España de los siglos XVI y XVII. Revista de Indias, Madrid, vol. LXIV, n. 232, 2004, p. 609-634. 
. El poder transfigurado: el virrey como "la viva imagen del rey" en la Nueva España de los siglos XVI y XVII. In: MAZÍN, Oscar (ed.). Las representaciones del poder en las sociedades hispánicas. Ciudad de México: El Colegio de México e Centro de Estudios Históricos, 2012, p. 301-335.

. Imaging the Spanish Empire: the visual construction of imperial authority in Habsburg New Spain. Colonial Latin American Review, London, vol. 19, n. 1, 2010, p. 29-68. doi: http://dx.doi.org/10.1080/10609161003643685

. The king's living image: the culture and politics of viceregal power in Colonial Mexico. New York: Routledge, 2004.

CARDIM, Pedro \& PALOS, Joan-Lluís (ed.). El mundo de los virreyes en las monarquías de España y Portugal. Madrid: Iberoamericana, 2012.

CARERI, Giovanni Francesco Gemelli. Viaje a la Nueva España. Ciudad de México: Unam, 1976.

CARMAGNANI, Marcello. El virrey y la corte virreinal en Nueva España. In: CANTÙ, Francesca (ed.). Las cortes virreinales de la Monarquía española: América e Italia. Roma: Viella Libreria Editrice, 2008, p. 65-77.

CASTIGLIONE, Baldassare. El cortesano. Madrid: Espasa-Calpe, 1984.

CRUZ, Sor Juana Inés de la. Obras completas. Ciudad de México: Fondo de Cultura Económica, 1976.

DORANTES DE CARRANZA, Baltasar. Sumaria relación de las cosas de Nueva España. Ciudad de México: Porrúa, 1987.

ELTON, Geoffrey Rudolph. Tudor government: the points of contact. Transactions of the Royal Historical Society, London, vol. 26, 1976, p. 211-228.

ESCAMILLA, Iván. La corte de los virreyes. In: RUBIAL, Antonio (ed.). Historia de la vida cotidiana en México, vol. 2. Ciudad de México: Fondo de Cultura Económica, 2005.

FRUTOS, Isabel Arenas. ¿Sólo una virreina consorte de la Nueva España? 16601664. La II Marquesa de Leiva y II Condesa de Baños. Anuario de Estudios Americanos, Sevilla, vol. 67, n. 2, 2010, p. 551-575. doi: http://dx.doi.org/10.3989/ aeamer.2010.v67.i2.519

GAGE, Thomas. Viajes por la Nueva España y Guatemala. Madrid: Historia 16, 1987.

GUIJO, Gregorio María de. Diario, 1648-1664. Ciudad de México: Porrúa, 1953.

LAFAYE, Jacques. Quetzalcóatl y Guadalupe: la formación de la conciencia nacional en México. Ciudad de México: Fondo de Cultura Económica, 1999.

LATASA, Pilar. ¿Criollismo peruano versus administración española? In: MAZZOTTI, José Antonio (ed.). Perú Hoy. Cambridge: David Rockefeller Center for Latin American Studies, 1999.

. La corte virreinal novohispana: el virrey y su casa, imágenes distantes del rey y su corte (s. XVII). In: CONGRESSO INTERNACIONAL DE AHILA: AMÉRICA LATINA: OUTRO OCCIDENTE? DEBATES DO FINAL DO MILENIO, 12. 2001, Porto. Atas... Porto: Centro Leonardo Coimbra, Faculdade de Letras da Universidade do Porto, 2001, p. 114-130.

. Poder y favor en la corte virreinal del Perú: los criados del Marqués de Montesclaros (1607-1615). Histórica, Lima, vol. 36, n. 2, 2012, p. 49-84. 
LYNCH, John. América latina, entre colonia y nación, Madrid: Crítica, 2001.

MILLÁN, José Martínez. La corte de la Monarquía Hispánica. Studia historica: historia moderna, Madrid, vol. 28, 2006, p. 17-61.

. (ed.). Las relaciones discretas entre la Monarquía Hispana y Portuguesa: las casas de las reinas (s. $X V$-XIX), vol. 3. Madrid: Polifemo, 2008.

MILLÁN, José Martínez E VISCEGLIA, María Antonietta (ed.). La monarquía de Felipe III, vol. 4. Madrid: Mapfre, 2008 .

OBREGÓN, Luís González. México viejo. Ciudad de México: Patria, 1966.

PALAFOX Y MENDOZA, Juan. Cartas del venerable siervo de Dios D. Juan de Palafox y Mendoza, Obispo de la Puebla de los Angeles, a el Rmo. Padre Andres de Rada. Madrid: Imprensa de don Manuel Martin, 1768.

PIDAL, Raúl Menéndez. Recopilación de las leyes de los reinos de Indias. Madrid: Cultura Hispánica, 1973.

PIETSCHMANN, Horst. La corte virreinal de México en el siglo XVII en sus dimensiones jurídico-institucionales, sociales y culturales: aproximación al estado de la investigación. In: BOSSE, Monika \& STOLL, André. La creatividad femenina en el mundo barroco hispánico: María de Zayas, Isabel Rebeca Correa, Sor Juana Inés de la Cruz. Erfurt: Reichenberger, 1999, p. 481-497.

PORRO GIRARDI, Nelly R. Los criados de los virreyes, un ingrediente de la corrupción en Indias. In: PINARD, Gustavo \& MERCHÁN, Antonio (ed.). Libro homenaje in memoriam Carlos Díaz Rementería. Huelva: Universidad de Huelva, 1998, p. 591-606.

ROBLES, Antonio de. Diario de sucesos notables (1665-1703). Ciudad de México: Porrúa, 1946.

RODRÍGUEZ, Manuel Rivero. Como reinas: el virreinato en femenino (apuntes sobre la Casa y Corte de las virreinas). In: MILLÁN, José María Martínez E LOURENÇO, Paula Marçal (ed.). Las relaciones discretas entre las Monarquías Hispana y Portuguesa: las Casas de las Reinas (siglos XV-XIX), vol. 2. Madrid: Polifemo, 2009, p. 789-818.

Court studies in the Spanish world. In: FANTONI, Marcello (dir.). The court in Europe. Roma: Bulzoni, 2012, p. 135-147.

. La edad de oro de los virreyes: el virreinato en la Monarquía Hispánica durante los siglos XVI y XVII. Madrid: Akal, 2011.

RUBIAL, Antonio. Las virreinas novohispanas: presencias y ausencias. Estudios de Historia Novohispana, Ciudad de México, vol. 50, 2014, p. 3-44.

. Monjas, cortesanos y plebeyos: la vida cotidiana en la época de Sor Juana. Ciudad de México: Taurus, 2005.

STERN, Steve J. La historia secreta del género: mujeres, hombres y poder en México en las postrimerías del periodo colonial. Ciudad de México: Fondo de Cultura Económica, 1999.

TORQUEMADA, Fray Juan de. Monarquía indiana. Ciudad de México: Unam, 1975.

VILLALOBOS, Arias de. México en 1623. In: GARCÍA, Genaro. Documentos inéditos ó muy raros para la historia de México. Ciudad de México: Porrúa, 1975, p. 367.

VILLAR, Ernesto de la Torre. Advertencias acerca del sistema virreinal novohispano. Anuario Mexicano de Historia del Derecho, Ciudad de México, vol. 3, 1991, p. 261-290. 

1991.

Instrucciones y memorias de los virreyes novohispanos. Ciudad de México: Porrúa,

ZAPATERO, Alberto Baena. Mujeres novohispanas e identidad criolla (siglos XVI y XVII). Alcalá de Henares: Ayuntamiento de Alcalá de Henares, 2009.

. Presencia y representación pública de las virreinas en la Nueva España, siglos XVI y XVII. Colonial Latin American Historical Review, Albuquerque, vol. 2, n. 1, 2014, p. 49-74.

. Una nueva perspectiva sobre la identidad criolla: la incorporación de las mujeres (s. XVI-XVII). Arenal: Revista de Historia de las mujeres, Granada, vol. 18, n. 2, 2011, p. 433-460.

Recebido: 20/05/2016 - Aprovado: 08/03/2017 